\title{
A Framework on Exploring Primary School English Language Teachers' Perceptions of their Continuing Professional Development in Malaysia
}

\author{
By Elaine Ling Ling Pang* \\ David Wray ${ }^{*}$
}

The national concern to improve in-service training (INSET) for English language teachers in Malaysia has led to the need to reshape continuing professional development $(C P D)$. CPD providers in Malaysia tend to conduct training using the cascade model and teachers are hardly consulted about their needs or learning preferences. This is likely to have a significant impact on the quantity and quality of INSET for teachers in a top-down national priority driven system. The research to be reported in this paper focuses on the perceptions of a group of Malaysian primary school English language teachers of their INSET experiences, the CPD models they prefer, and their perceptions of the effect of CPD on their classroom practice. The research also aims to identify their future expectations of INSET in terms of their professional development needs and their pupils' needs. Qualitative survey research was undertaken using profile questionnaires, focus group interviews and individual interviews, followed by an online survey of all research participants. The researcher followed the CPD journey of three groups of primary school educators, selected using convenience sampling and purposeful sampling. This paper suggests a framework to investigate teachers' views about their needs. This would shed light on how CPD providers can enhance teachers' professional development and thus student achievement.

Keywords: continuing professional development (CPD), framework, in-service training (INSET), teacher education.

\section{Introduction: The Wider Context of the Study}

Malaysia uses an outcome based education system. The national curriculum document states that by the end of their educational experience, pupils should have achieved the goals set out in the curriculum. In order to train English teachers in Malaysia in a short time to implement the new curriculum, the cascade model of continuing professional development (CPD) is preferred. It uses the top-down model of curriculum development.

This study explores the perceptions of a group of teachers' on their CPD journey and capture their views on the types of CPD activities they experience based on their beliefs of what good CPD is. Their views are pertinent as they have given suggestions on how the whole process of In-Service Education of Teachers (INSET) could be improved to cater to their individual needs,

${ }^{*}$ PhD Student, University of Warwick, UK.

${ }^{\dagger}$ Professor, University of Warwick, UK. 
students' needs, school needs and national needs. This paper suggests a framework to investigate teachers' views about their professional development needs. This would shed light on how CPD providers can enhance teachers' professional development and thus student achievement. The findings presented was obtained from the field work which was conducted between May to July 2015.

\section{Background}

There is a national concern to improve the level of education in Malaysia and this has led the Ministry of Education to revise the national curriculum. In 2010, the Ministry introduced the Malaysian Curriculum Standard Document (KSSR) and in 2013, the Malaysia Education Blueprint (2013-2025) introduced eleven shifts to transform the education system (Ministry of Education Malaysia, 2013).

In line with this transition, one of the shifts aimed to upgrade the quality of CPD for teachers. This has led to a reshaping of the type of courses and the delivery mode for CPD on a national level. In 2014, the Ministry of Education (Teacher Education Division, 2014) introduced the CPD Masterplan (Pelan Pembangunan Professionalisme Berterusan) which aimed to be implemented together with the shifts outlined in the Malaysia Education Blueprint.

\section{Literature Review}

The literature review explores some of the complexity of curriculum and curriculum development and how it is related to teachers' CPD and INSET. This is followed by a review of the importance of teacher quality in pupils' achievement in school, professional development and INSET for teachers. Pring (2011) emphasized that curriculum development and professional development are intertwined and there can be no curriculum development without teacher development. Thus, teachers' professional development is viewed as a key school factor impacting students' achievement (William, 2013).

The "Curriculum" is complex. Teachers are curriculum designers as they make decisions about what to teach and when to teach it (Macalister \& Nation, 2011). The intended curriculum, enacted curriculum and assessed curriculum fall under the category of prescriptive curriculum (Ellis, 2004 in Glatthorn, Boschee, \& Whitehead, 2005). The learned curriculum and hidden curriculum, also known as the unstudied curriculum falls under the descriptive curriculum, relating to experience (Glatthorn, Boschee, \& Whitehead, 2012). According to Stenhouse (1989), the curriculum is the reality of what is happening in the school. Eggleston (2000) emphasized the research by Bernstein (1971) showing that how schools make the curriculum available to pupils is one of the main determinants of the pupils' success in the future. 
Print believes (1993) that the curriculum is of great importance to teachers as they are heavily influenced by its requirements. It is often suggested, e.g. DeConick (2008) that curriculum and curriculum development are the responsibility of governments and teachers. But curriculum and curriculum development are complex, involving policies, goals, areas of study, units and lesson plans. Glatthorn (2012) suggests that the curriculum is a plan made for guiding learning in schools. Teachers are central to the creation of the curriculum and the development of the curriculum goes hand in hand with teacher development (Pring, 2011). Teachers are also researchers of what works in the classroom and act as curriculum thinkers based on the evidence they see and gather in their practice (Pring, 2011).

There is a great emphasis upon professional development for teachers although the central role of the teacher has been often overlooked by policy makers who focus on students' high achievements (Fullan, 2007). Research by CUREE (2012) suggests that professional development contributes highly to student learning outcomes. CUREE (2012) also emphasized four effective CPD approaches; collaborative enquiry, coaching and mentoring, networks between schools and using structured dialogues and group work for teachers to try out new approaches. Based on research by Hattie (2009) and Rand Education (2012), the teacher factor seems more important for pupils' achievement than any other school factor. There is thus an urgent need to pay more attention to CPD and focus more closely on teachers and learners' needs. In addition, concentrating on teachers' CPD is the most effective way to make a difference to pupils' learning outcomes as their previous attainment cannot be changed (Hattie, 2009).

Pupils' achievement is influenced by their parents, extended family, peers, neighbourhood, schools and society generally. Their success is based on the school's capacity to cater to their specific educational needs (Mincu, 2013). Desforges and Abouchaar (2003), Epstein et al (2002) and Harris and Goodall (2007) emphasized that the strongest influence on pupils' achievement is parental background. Research on school factors influencing pupils' achievement has found teachers to be the most important factor (Sammons \& Ko, 2008; Hargreaves \& Fullan, 2012; Rand Education, 2012; William, 2013). Hattie (2009) found that teacher clarity, teachers' professional development and teaching strategies ranked highly in influencing pupils' academic achievement. Thus, it is logical to suggest that achievement can be raised if the quality of teachers improved (Juerges, Richter, \& Schneider, 2004). Some initiatives to do this involve CPD, e.g. providing mentoring programmes and getting teachers to collaborate and share skills (Joyce \& Showers, 1996). Teachers' professional development does impact pupils' achievement although it is difficult to identify the exact factors that influence the improvement and how much they contribute (Thompson, 2003). Nevertheless, Kempton (2013) emphasized that teacher quality is vital for pupils to achieve good academic performance.

A crucial aspect of curriculum development involves staff development (Wiles, 2009). The role of the teacher has come under scrutiny in recent years 
(Hargreaves \& Fullan, 2012). The quality of teaching seems to depend on their professional development (Craft, 1996). Day (1999) defines CPD as all natural learning experiences with opportunities for teachers to review, renew and extend their professional activities in ways which benefit the teacher, students, school and the quality of education in their classrooms.

Enhancing teacher quality through CPD is recognised as dynamic and continuous throughout a teacher's career (Schleicher, 2011). Kempton (2013) emphasized that effective CPD is one way to ensure having high quality teachers and it is vital to train the teachers properly. One of the problems lies in CPD experiences which are disconnected from the classroom (Pedder \& Opfer, 2013). CPD should be embedded in a full range of professional activities and contexts to be effective, involving teachers learning in collaboration (Bolam et al., 2005). Day and Leitch (2007) believe CPD should include opportunities for teachers to focus on subject matter that includes hands-on practice to be integrated into their daily teaching.

In Malaysia, most CPD for in-service English teachers uses the cascade model, an apparently cost effective means to bring educational change to a large population of teachers (Wedell, 2005). This model is used in contexts where there are limited resources (Kennedy, 2005). Dissemination of a central approach is built into the initial learning process (Craft, 1996). The cascade model is used in contexts where there are limited resources, such as lack of skilled trainers (Kennedy, 2005). According to Craft (1996), dissemination of information is built into the initial learning process, to disseminate a central message or approach which is proposed.

The cascade model comes under the training model and often employs a trainer or a small team of trainers to train a large group of teachers (McDevitt, 1998). The first pool or level of teachers will then train another group of teachers. It uses a chain effect and there is no limit to the number of groups trained by those trained in each link. However, the norm of the number of links is three to four groups down the cascade model. In theory, the quality of content which is passed down from the first group to the last group should be similar because the training is often delivered as the same package (McDevitt, 1998). Nevertheless, a smooth transfer of knowledge is not always achieved as the ideas may get distorted if not clearly understood by the first group of teachers being trained. Wedell (2005) stressed that the cascade model is not a guarantee of the training aims being applied in classrooms.

Wedell (2005) also emphasizes that when using the cascade model, a key focus is to consider the context and content of the training. The initial planning stage should identify whether there is a mismatch between programme aims, the subject and realities in the classroom. The audience for the cascade model has to be well defined the teachers' needs targeted carefully in order for the training provided to be effective and relevant to them (Craft, 1996). One of the greatest strengths of the cascade model is the training role given to the facilitators at each level or link (McDevitt, 1998). Teachers who have gone through the first level of training will have the experience to take on the role of trainers in their districts or schools etc. It indirectly gives them a dual role as a 
participant first and then a trainer (Wedell, 2005). This fosters professional development and staff development for them, enabling them to become more familiar with the content.

In contrary, it could also be a problem if the transition period given to the teachers are very short, should they need to become "active" facilitators right after completing the initial training (Mcdevitt, 1998). In terms of practicality, they would actually need time to understand the ideas and key concepts and do further exploration of the content area before being able to train others.

Wedell (2005) further explains that the 'dual' role given to the teachers is similar to expert coaches. This is true especially for teachers who serve as trainers to do smaller scale training programmes in district or state levels. Nevertheless, Joyce and Showers (1996) are of opinion that these trainers or expert coaches will still need some form of active coaching before they will be fully ready to conduct training. It would help to develop their confidence and competence in the content area.

The cascade model's strength is also training as many teachers as possible in a shorter period of time (Wedell, 2005). More teachers will be able to receive hands-on experience of the proposed content, skills and teaching techniques to maximise the impact in the classroom. Thus, it is an economical way of getting the training done with less materials and less master trainers. In most cases, preparation will include one module or package and a small group of skilled trainers to train the first group. In contrast, Dichaba and Mokhele (2012) reported that in spite of the cascade model being an accepted method of training teachers for INSET, it did not succeed to improve the performance of teachers in the context of the research.

CPD is indeed a complex and long-term process (Neil \& Morgan, 2005) and it seems crucial not to adopt a quick fix approach (Bates, Gough, \& Stammers, 1999). Harland et al. (1999) emphasized the best learning is slow learning. There is also the question of the right teachers attending the right courses which is linked to the balance between individual, school and national needs. There are dangers in a top-down national priority driven structure of CPD which Graham (1996) believes is related to a shift from a knowledge and values base of education to the instrumentality of training.

Training and educating teachers can be seen as a problematic concept. There is a fine line between both but it is difficult to separate the two as they are related. Lieberman (1996) uses the term, an 'expanded view of professional learning' to explain the educating of teachers. Teachers also go through informal development opportunities in school and attend formal "accelerated" learning opportunities such as training. The training could be available through internal CPD programs at school level or externally run INSET programs on a national level.

Lieberman (1996) also classified CPD into three categories; direct teaching, learning in school and out of the school learning. INSET would come under direct teaching where teachers attend courses, workshops and have consultations with their trainers. This classification is significant because it highlights the educating of teachers which occur through informal learning and 
which grows from the purpose and direction of a teacher's own work, the sense they make out of their understanding of what works and what does not. Lieberman's work also pointed out that formal education and training only contributes a small proportion to teachers' learning. Teachers need to be educated in and out of the work place as both are crucial in their CPD and this strongly suggests a learner-focused perspective as being more crucial than a training-focused perspective in planning and managing CPD for teachers.

Omar (2014) suggests that INSET is a catalyst for the effectiveness of teachers as it leads to better job performance with updated knowledge and skills as well as helping teachers when they face challenges and need to keep up with changes in education. They will be able to apply the knowledge and skills gained into their teaching. Thus, it leads to teacher professionalism and motivates teachers to perform better in their teaching.

\section{Focus of Research}

This research reported here focused on investigating the CPD needs of Malaysian primary school English language teachers. I selected this area because the literature suggests that teachers have to deal with many issues such as the complexity of the curriculum as well as the complexities of CPD. There are many underlying issues which influence a teacher's performance in the classroom which are unseen by other parties who focus and insist on the quality of teachers in relation to pupils' achievement.

The planners and providers of CPD in Malaysia follow the top down model to plan teachers' INSET courses. The teachers are hardly consulted on their perceived needs and learning preferences. This is likely to have a significant impact on the quantity and quality of INSET courses provided for teachers. These are risks in a top-down, national priority driven training system.

The first step was to find out teachers' views and beliefs about INSET as this would shed some light on their needs perceived by themselves rather than by the central governing agency which decides on the INSET needed nationally. Phillips (2014) suggested that teachers might know best, as they are eager to improve their craft of teaching and listening to teachers is necessary to assist them in their professional development.

\section{Research Methodology}

The area of investigation was determined after closely analysing themes from the literature review. It was clear that an investigation into teachers' views of their INSET could give a clearer picture of their perceived needs for CPD. It would also provide some information on the CPD models and activities teachers prefer which would be useful to the providers of INSET in Malaysia. 


\section{Aims and Objectives and Research Questions}

The research therefore aimed to identify the perceptions of a group of Malaysian primary school teachers regarding their previous CPD activities, the models they prefer, relevance to the curriculum and the perceived effects on changes in their practice. In addition, the research also aimed to identify the future expectations about INSET of a group of Malaysian primary school teachers in terms of their professional development needs and their pupils' needs.

The dual objectives relate to three research questions; what are teachers' perceptions of their experiences of INSET courses and which CPD models do they prefer; how relevant are the INSET courses to the curriculum and does it help teachers to improve in their practice; what are teachers expectations for short and long INSET courses in relation to their needs and their pupils' needs?

This paper is a case study which draws upon data from a broader piece of on-going research which is informed by the qualitative survey approach. The qualitative survey approach does not use frequencies, means or statistical analysis to determine diversity in a given population on a particular topic. Instead, this approach establishes variation in terms of values and dimensions that are meaningful within that population (Jensen, 2010). Thus, this approach is a study of diversity in a population as compared to distribution in a quantitative survey approach. Jensen (2010) emphasized that the survey is a systematic method to obtain information to construct quantitative descriptors of a large population. However, it only observes individual characteristics of members and does not observe social interactions between people in a particular population. In contrast, the qualitative survey is an approach to define and investigate variation in populations. In addition, Fink (2003) stated that qualitative surveys are used to obtain information on meanings people attach to their life experiences and how they share and express them.

\section{Research Site and Sampling}

The study took place in one Training Centre which provides INSET for English language teachers in Malaysia from May to July 2015. Teachers come from all over Malaysia and attend the INSET courses in one central location, at the English Language Teaching Centre (ELTC), Malaysia.

The aim was to present the experience and views of the research participants in a detailed manner for the reader to connect their experiences and have a deeper understanding of the issue (Alvesson, 2011). In the study, the researcher followed the progress of 3 groups of primary school English language teachers and school improvement specialist coaches (SISCs) on their INSET journey. They were initially selected using convenience sampling as there were about 30 teachers pre-selected by their state education English language officers for each INSET course. Then, purposive sampling was used in the next stage to select eight teachers from each INSET course for the focus groups. They were selected based on number of years of teaching experience, 
teaching the English language, CPD activities they have attended, age and gender. Finally, volunteer sampling was used to identify the participants for the individual interviews as they were given the opportunity to volunteer. However, this paper presents a case study and only focuses on data gathered from two research participants (A and B) who completed the $1^{\text {st }}$ INSET course, "Specialist Certificate in Literacy Development for Lower Primary Students".

\section{Research Methods}

The research used 4 instruments for data collection to collect multiple sources of data. They were profile questionnaires, focus group interviews, individual interviews and a post survey. The intended sample for this study was based on the name list from the State Education Departments and was expected to be 90 participants. However, the sample for this study was only the 55 participants who actually attended and completed the INSET courses.

The profile questionnaires were short questionnaires for the participants to give details about their educational background, teaching experiences and CPD attended. The focus group interviews and individual interviews used semistructured questioning. A total of 21 participants were selected and divided into 6 focus groups with 3 or 4 participants in each. Another 16 participants took parts in individual interviews and each participant took part in 2 interviews. A post survey will be sent to the population sample after the data analysis of the data from the focus groups and individual interviews are completed.

\section{Data Analysis}

In order to analyse the data that was collected, preliminary data analysis was done after transcription was completed for the data from each INSET course. The researcher noted short notes of issues emerging and began to code the data using these emerging points. The next stage was to identify emerging themes from the coding.

\section{Results}

This paper focuses on a case study of data gathered from two research participants (A and B) who completed the $1^{\text {st }}$ INSET course, "Specialist Certificate in Literacy Development for Lower Primary Students".

\section{Profile of the Participants}

In Malaysia, English language teachers consists of optionist and nonoption teachers. Optionists are teachers who had specialize in the English language known as their "option" during pre-service training. Non-option teachers are those who do not have any prior pedagogical training on how to teach the English language and have specialized in other subjects but are 
required to teach the English language as there are not enough optionists to cater to the need in schools.

The two research participants were female English language primary school teachers currently teaching in national type government primary schools in Malaysia. They were also "optionist", with TESOL/ TESL training to teach the English language at primary level. Table 1 provides the participants' profile details.

Table 1. Participants' Demographics

\begin{tabular}{|l|c|c|}
\hline Profile & A & B \\
\hline Age & 50-59 & $30-39$ \\
\hline Qualifications & $\begin{array}{c}\text { Master in Education } \\
\text { Bachelor Degree }\end{array}$ & Bachelor Degree \\
\hline Teaching Experience & $26-30$ years & $11-15$ years \\
\hline Teaching English & $26-30$ years & 6-10 years \\
\hline Types of CPD attended in last 2 & Courses & Courses \\
years & Workshops & Workshops \\
& Conference/Seminar & Mentoring \\
& Observation visits & Peer Observation \\
& Mentoring & \\
\hline & Peer Observation & \\
\hline
\end{tabular}

\section{Teachers' Perceptions of Previous INSET Programmes}

The two participants had been teaching English language and were offered the role as a school improvement specialist coach (SISC) in the previous year. For the purpose of the interviews, they reflected on their experience of attending INSET courses while they were teaching in primary schools.

On the types of INSET courses attended in the past 2 years, both participants explained that they attended only short INSET course for 3 to 4 days duration. Most of these courses were conducted off-site at a training centre, usually in the capital city of their home states or the capital city of Malaysia, Kuala Lumpur as it was accessible by all course participants from across Malaysia.

Participant A highlighted that the INSET courses were staggered throughout the year and planned by the CPD planners, at a central location by teacher trainers of the Ministry of Education, Malaysia. In contrast, participant B was teaching in a small school with only 150 pupils. There were only 2 English language teachers in the school so each teacher was in charge of one level; lower primary and upper primary and were always selected by the English language officer in the state department. Both participants were directed by their state education departments to attend all the INSET courses free of charge and accommodation and food was provided by the Ministry of Education.

Participant A explained that most of the INSET courses were very intensive and sometimes the same cohort of 30 teachers from a state were sent for other INSET training. In addition, some courses required the participants to 
prepare and action plan and participant $\mathrm{A}$ found this quite a demanding task as they had to implement it after the course. Participant B shared that once nominated, it was compulsory for the teachers to attend INSET and they needed the knowledge and the certificate especially since her $1^{\text {st }}$ degree was in the Malay language.

\section{Teachers' Perceptions of Program Experience}

Both participants had positive views about attending this INSET course. Participant A stated that many issues in her mind were resolved after attending this course, especially on phonics. She explained that most teachers were still using which were not effective to teach phonics. She found the group presentations most helpful as the participants were able to discuss problems they faced with other educators who had a vast range of teaching experience. She also shared that the facilitator should not intervene during their discussion.

Participant B rated the INSET course an 8 out of 10 and explained that she preferred courses which had workshops and required participants to engage in hands-on activities. She did not want to attend mass lectures which focused on delivery of content. Participant B also explained that she preferred INSET courses on English literature and phonics instead of generic INSET courses on management. On the other hands, she mentioned that ICT courses were important as teachers needed knowledge in that area.

\section{Teachers' Aspirations and Future Expectations of INSET}

Participant A explained that about $80 \%$ of INSET courses she had attended met her expectations because some of the trainers were new and "picking up along the way". The participant's opinion on the criteria for a good INSET course covered good input given by the trainers and giving the course participants time to present their work during workshops. In addition, it should give the teachers an opportunity to improve in their public speaking skills in English. Participant B shared similar views and added another important criteria which was to plan INSET courses which involved the 5 senses. This included activities which gave all course participants opportunities to learn. She also shared that the biggest issue for teachers was that they were reluctant to change and not ready to do so although they needed the new knowledge. She also stated "you cannot cater for all teachers in Malaysia" and the training in INSET courses could be shared between teacher trainers, SISCs and district English language officers (ELOs).

\section{Discussion and Conclusion}

Malaysia has one of the lowest student to teacher ratios in the world and currently stands at 13:1 as compared to the OECD average of 16:1 (Ministry of Education, Malaysia, 2013). The expansion of the workforce has created a 
workforce which majority of younger teachers who will still be in the teaching profession for the next 20 to 30 years. Thus, the quality of teachers is very significant to determine pupil outcomes and achievement.

This study examined the unsettled issue of what were teachers' perceptions of INSET courses they had attended in Malaysia and what were their future expectations for INSET and the provision of CPD for primary school educators. They research also suggests an urgent need to enhance the competency of trainers and provide practical hands-on activities in workshop style sessions for INSET as some teachers prefer that as compared to a lecture style session with input.

The preliminary findings of this study indicate overall that these teachers did have a strong sense of the importance of their professional development. They shared pertinent views in their perceptions of INSET courses they had attended over the previous 15-30 years as English language primary school teachers in Malaysia. They have many opportunities to attend INSET courses with no costs involved.

The research participants highlighted a few factors which made the INSET courses relevant to them and these concerned the content that was needed by the teachers such as English literature, phonics and literacy related issues. They believed there should be more INSET courses which were content related rather than generic INSET courses on topics related to administration. The teachers' needs to attend the specific courses they mentioned is related to the content in the primary school curriculum and is also related to the teachers' needs of not only professional development but the inclusion of professional growth and lifelong learning. It does not end with their professional development in teaching as they will acquire new skills by attending INSET and develop their competencies, qualifications and seek new innovations to teach the subject matter.

The participants stressed that most teachers were reluctant to change because they were not aware of the new knowledge and once they had been given the input, the choice was theirs to take a positive step towards change. They were not resistant to INSET participation and were comfortable to attend INSET courses selected for them and prescribed in a top-down, one size fits all, expert driven model. Nevertheless, the willingness to change is also related to teachers' readiness to gain new knowledge, useful experiences and receptiveness to look at things from a different perspective to improve in their craft of teaching and daily practice in the classroom. In addition, reluctance and willingness to change is also linked to fears and uncertainties to accept the need to change in certain practices after attending INSET for professional development.

Limitations of this study should be acknowledged as the study focuses on the perceptions of participants who were attending three INSET courses in one Training Centre. In addition, the limitations have created a pathway for further in-depth investigation into the issues that have emerged for the data analysis. 


\section{References}

Alvesson, M. (2011). Interpreting interviews. London: SAGE.

Bates, T., Gough, B., \& Stammers, P. (1999). The role of central government and its agencies in the continuing professional development of teachers: an evaluation of recent changes in its financing in England. Journal of In-Service Education 25(2).

Bolam, R., McMahon, A., Stoll, L., Thoman, S., Wallace, M., Greenwood, A., Hookey, K., Ingram, M., Atkinson, A and Smith, M. (2005). Creating and sustaining effective professional learning communities. Research Report No. RR637. ISBN 1844784606. United Kingdom: University of Bristol.

Craft, A. (1996). Continuing professional development: A practical guide for teachers and schools. London: Routledge.

CUREE (2012). Understanding What Enables High Quality Professional Learning. A Report on the Research Evidence. Centre for the Use of Research Evidence in Education (CUREE), Pearson School Improvement. London, UK.

Day, C. (1999). Developing teachers: the challenges of lifelong learning. London: Falmer Press.

Day, C. \& Leitch, R. (2007). The continuing professional development of teachers: issues of coherence, cohesion and effectiveness. In T. Townsend, (Ed) International Handbook of School Effectiveness and Improvemen, 702-726. Springer.

DeConinck, C. (2008). Core affairs: Flanders, Belgium: Case studies basic education in Europe. Enschede, Netherlands: SLO-Netherlands Institute for Curriculum Development. Retrieved from http://bit.ly/2c4dpTL.

Desforges, C., \& Abouchaar, A. (2003). The impact of parental involvement, parental supportand family. Education on pupils achievement and adjustment: a literature review. Research Report No. 433. ISBN 1841859990.

Dichaba, M.M., \& Mokhele, M. L. (2012). Does the cascade model work for teacher training: Analysis of teachers' experiences. International Journal of Educational Sciences 4(3), 249-254.

Eggleston, J. (2000). Staying on at school - The hidden curriculum of selection. Warwick Papers on Education Policy no. 9. Great Britain: Trentham Books Limited.

Epstein, J.L, Sander, M.G, Simon, B.S, Salinas, K.C, Jansorn, N.R, Voorhis, F.L. (2002). School, Family and Community Partnerships: Your Handbook for Action $\left(2^{\text {nd }}\right.$ ed.). USA: Thousand Oaks.

Fink, A. (2003). The survey handbook ( $2^{\text {nd }}$ ed.). USA: SAGE Publications.

Fullan, M. (2007). The new meaning of educational change ( $4^{\text {th }}$ ed.). USA: Teachers College Press.

Glatthorn, A.A, Boschee, F.A., \& Whitehead, B.M (2005). Curriculum leadership: Strategies for development and implementation. USA: Sage.

Glatthorn, A.A, Boschee, F.A., \& Whitehead, B.M (2012). Curriculum leadership: strategies for development and implementation (3rd ed.). USA: Sage.

Graham, J. (1996). The teacher training agency: Continuing professional development policy and the definition of competencies for serving teachers. British Journal of In-Service Education 22(2), 121-132.

Hargreaves, A. \& Fullan, M. (2012). Professional capital: transforming teaching in every school. USA: Teachers College Press.

Harris, A., \& Goodall, J. (2007). Engaging parents in raising achievement. do parents know they matter? A research project commissioned by the specialist schools and 
academics trust. Research Report DCSF - RW004. University of Warwick. Retrieved from http://bit.ly/2cFM12n.

Hattie, J. (2009). Visible learning. Hattie ranking: Influences and effect sizes related to student achievement. Retrieved from http://bit.ly/1 krblRE.

Harland, J., Ashworth, M., Atkinson, M., Halsey, K., Haynes, J., Moor, H., \& Wilkin, A. (1999). Thank you for the days? How schools use their non-contact days. UK: National Foundation for Educational Research (NFER).

Jensen, H. (2010). The logic of qualitative survey research and its position in the field of social research methods. Forum: Qualitative Social 11(2), Art. 11-May 2010.

Joyce, B., \& Showers, B. (1996). The evolution of peer coaching. Educational Leadership 53(6), 12-16.

Juerges, H, Richter, W.F., \& Schneider, K. (2004). Teacher quality and incentives: theoretical and empirical effects of standards on teacher quality. CESifo Working Paper No.1296. Institute for Economic Research.

Kempton, J. (2013). To teach, to learn: more effective CPD for teachers. London: Centre Forum.

Kennedy, A. (2005). Models of continuing professional development: a framework for analysis. Journal of In-Service Education 31, 235-250.

Lieberman, A. (1996). Practices that support teacher development: transforming conceptions of professional learning. In M.W. McLaughlin, \& I. Oberman, (Eds), Teacher Learning: New Policies, New Practices. New York, USA: Teachers College Press.

Macalister, J. \& Nation, I.S.P. (2011). Case studies in language curriculum design. Concepts and approaches in action around the world. USA: Routledge.

McDevitt, D. (1998). How effective is the cascade as a method for disseminating ideas? A case study in Botswana. International Journal of Educational Development 18(5), 425-428. Great Britain: Pergamon.

Mincu, M. (2013). Teacher quality and school improvement: What is the role of research? Research and Teacher Education: The Bera-RSA Inquiry. British Educational Research Association.

Ministry of Education, Malaysia (2013). Malaysia Education Blueprint 2013 - 2025.

Neil, P., \& Morgan, C. (2005). Continuing professional development for teachers: from induction to senior management. Great Britain: Taylor \& Francis e-library.

Omar, C.M.Z. (2014). The need for in-service training for teachers and it's effectiveness in school. International Journal for Innovation Education and Research 2(11). Retrieved from http://bit.ly/2cjVXuI

Pedder, D., \& Opfer, V. D. (2013). Professional Learning Orientations: Patterns of Dissonance and Alignment between Teachers' Values and Practices. Research Papers in Education 28(5), 539-570.

Phillips, V. (2014). Teachers Know Best: Teachers Views on Professional Development. Bill and Melinda Gates Foundation. Retrieved from http://bit.ly/2c jRbQ0.

Print, M. (1993). Curriculum development and design ( $2^{\text {nd }}$ edition). Sydney, Australia: Allen \& Unwin.

Pring, R. (2011) Trusting teachers: Learning from a bit of history. Education Review, 23(2). United Kingdom: The Education Publishing Company Ltd.

Rand Education (2012). Teachers matter: understanding teachers' impact on student achievement. Retrieved from http://bit.ly/1kG80ET.

Sammons, P., \& Ko, J. (2008). Using systematic classroom observation schedules to investigate effective teaching: Overview of quantitative findings. An effective classroom practice project report. Swindon: ESRC. 
Schleicher, A. (2011). Building a high- quality teaching profession: lessons from around the world. OECD Publishing. Retrieved from http://bit.ly/2ccOsHj.

Stenhouse, L. (1989). An introduction to curriculum research and development. Great Britain: Heinemann.

Teacher Education Division (2014). Pelan Pembangunan Profesionalisme Berterusan [CPD Masterplan]. Ministry of Education, Malaysia.

Thompson, S. (2003). Creating a high performance school system. Phi Delta Kappa International 84(7), 489-495. Retrieved from http://bit.ly/2c9ZDQv.

Wedell, M. (2005). Cascading Training Down into the Classroom: The Need for Parallel Planning. International Journal of Education Development 26(6), 637651.

Wiles, J. (2009). Leading curriculum development. USA: Corwin Press.

William, D. (2013). The importance of teaching. In J. Clifton (Ed.) Excellence and Equity: Tackling Educational Disadvantages in England's Secondary Schools. London: Institute for Public Policy Research. 